\title{
Program Aplikasi Data Terpadu Unit Pelaksana Teknis Perawatan dan Perbaikan di Politeknik Negeri Sriwijaya Berbasis WEB.
}

\author{
Ridwan Effendi' ${ }^{1)}$, Zulkarnaini' ${ }^{2}$, Robinson ${ }^{3)}$, Deri Arfin ${ }^{4}$ \\ Jurusan Manajemen Informatika \\ Politeknik Negeri Sriwijaya \\ Email : $\underline{\text { ridwaneff@gmail.com }}$
}

\begin{abstract}
Abstrak
Unit Pelaksana Teknis Perawatan dan Perbaikan (UPT-PP) adalah Unit Kerja yang ada dalam Organisasi Politeknik Negeri Sriwijaya (POLSRI), bertugas dan bertanggung jawab dalam perawatan dan perbaikan alat. Unit kerja ini, yang dalam perkembangannya memerlukan media dalam memberikan data dan informasi pelayanannya kepada unit lainya, serta laporan kinerjanya pada atasan. Untuk mendorong layanan unit kerja ini lebih maju, maka akan dibuatkan Program aplikasi menggunakan bahasa pemrograman PHP dengan Basis Datanya akan didukung oleh MySQL. Perancangan Aplikasi ini akan mengunakan sistem Modeling. Aplikasi ini selanjutnya akan diungah ke Sistem berupa Website. Aplikasi akan memungkinkan unit organisasi yang ada dilingkungan Politeknik Negeri Sriwijaya mendapatkan melaporkan perbaikan alat dan dapat dimonitor perkemangannya setiap saat, sampai peralatan tersebut selesai diperbaiki untuk diambil dan digunakan kembali. Pada Tingkat Pengawas, dapat melihat laporan Perawatan dan Perbaikan, serta kenerja oganisasasinya .
\end{abstract}

Kata kunci: UPT PP , PHP, MySQL, Website

\section{Pendahuluan}

Politeknik Negeri Sriwijaya (Polsri) adalah perguruan tinggi negeri yang berada di kota Palembang. Polsri mimiliki unit-unit pelayanan yang memberikan pelayanan dibidang pendidikan, kewirausahaan teknis maupun kesehatan. Salah satunya adalah unit pelaksana teknis perawatan dan perbaikan (UPT-PP).

UPT-PP memiliki tugas dan tanggung jawab dalam perawatan dan perbaikan alat di lingkungan Politeknik Negeri Sriwijaya. Pengelolaan data dan informasi yang saat ini pada UPT-PP masih perlu pengembangan, karena proses penyampaian data dan informasi kerusakan, perbaikan dan pemeliharaan barang dari jurusan, bagian atau unit masih melalui telepon atau mengharuskan teknisi pada tiap jurusan, bagian atau unit datang langsung ke UPT-PP. Penyimpanan dan pencatan data Perbaikan dan perawatan Barang, dilakukan menggunakan Microsoft Excel. Pelaporan kinerja UPT-PP ini, kepada atasan menggunakan dukumen hasil cetak yang diarsipkan burupa Bundel Arsip. Hal ini memerlukan waktu relatif lama dalam mengaksesnya. Dokumen cetak data dan informasi tersebut memerlukan ruang dan tempat yang harus rapi penataan. Apabila data atau informasi tersebut diambil dan tidak dikembalikan ditempatnya semula, maka selanjutnya akan sulit menemukannya kembali.

Ada beberapa aplikasi untuk mendukung pembuatan database yaitu: Microsoft SQL Server, Microsoft Access, Oracle dan lainnya tergantung pada kebutuhan. Penggunaan database ini sangat diperlukan seiring dengan perkembangan informasi begitu cepat dan dinamis.

Sistem basisdata yang sudah tersusun dengan baik, akan sangat membantu ketika membuat aplikasi baru, sehingga pembuat program hanya perlu membuat tampilan tatapmuka (Interface) yang dibutuhkan.

UPT-PP dalam kegiatan sehari-harinya mengolah data untuk layanannya, akan sangat terbantu, apabila terdapat Program Aplikasi berbasis Web, yang dibuat khusus untuk kegiatannya yang rutin. Aplikasi Berbasis Web, memiliki Keunggulan, yaitu: 1) Aplikasi berbasis web dapat dijalankan dimanapun kapanpun tanpa harus melakukan instalasi. 2) Tidak diperlukan lisensi ketika menggunakan 
web-based application, sebab lisensi telah menjadi tanggung jawab dari web penyedia aplikasi. 3) Dapat dijalankan di sistem operasi manapun, seperti linux maupun windows, asalkan terdapat browser dan akses internet. 4)Dapat diakses lewat banyak media seperti: Komputer atau Telepon Genggam yang sudah sesuai dengan standard WAP. 5) Tidak perlu spesifikasi komputer yang tinggi

Untuk memenuhi kebutuhan dan tuntutan di atas peneliti mencoba membuat Program Aplikasi Data Terpadu Unit Pelaksana Teknis Perawatan dan Perbaikan di Politeknik Negeri Sriwijaya Berbasis WEB.

\section{Metode Penelitian}

Metode yang digunakan dalam penelitian ini adalah metode deskriptif analisis dengan pendekatan kualitatif, yaitu penelitian yang lebih menekankan pada aspek pemahaman secara mendalam terhadap suatu masalah yang kemudian diolah dan dianalisis untuk diambil kesimpulan.

\subsection{Kerangka Konseptual Penelitian}

Kerangka konseptual merupakan suatu bentuk

kerangka berpikir yang dapat digunakan sebagai pendekatan dalam memecahkan masalah. Kerangka penelitian ini menggunakan pendekatan ilmiah dan memperlihatkan hubungan antar variabel dalam proses analisisnya. Adapun kerangka berpikir dalam penelitian ini dapat digambarkan sebagai bekikut:

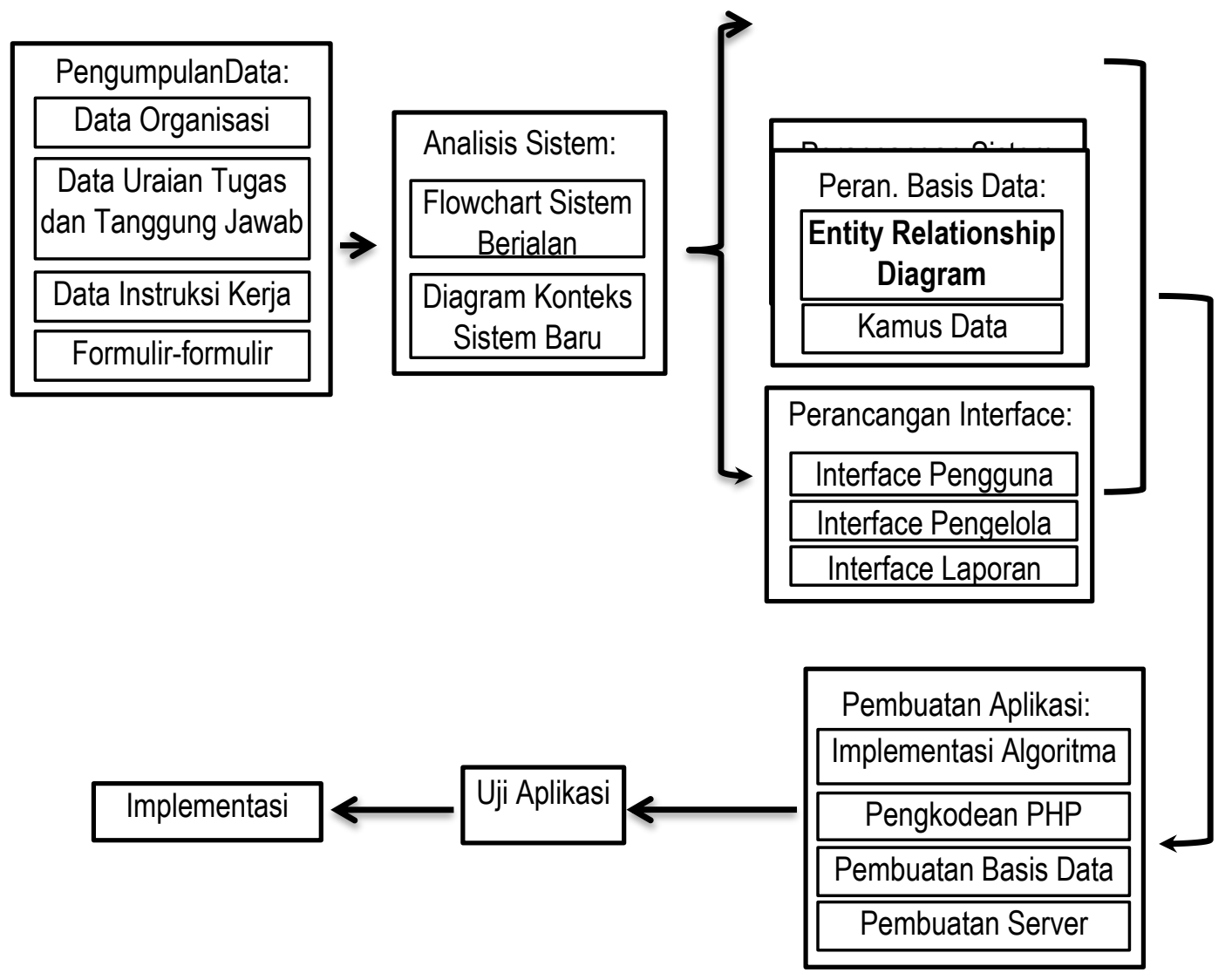

Gambar 1. Kerangka Konseptual Penelitian

2.2. Tahap-tahap pembangunan Perangkat Lunak

Rekayasa atau pembangunan perangkat lunak ini menggunakan metode Rational Unified Process (RUP), dengan aktifitas yang sebagian besar berfokus pada pengembangan model dengan menggunakan Unified Model Language $(U M L)$. Terdapat empat tahap pengembangan perangkat lunak, yaitu: 


\section{1) Permulaan (Inception)}

Tahapan Permulaan ini dimulai dengan pengumpulan data kegiatan-kegiatan yang ada didalam sitem. Data ini didapatkan melalui 3 cara yaitu wawancara, observasi, dan analisis dokumen.

Berdasarkan studi pendahuluan yang meggunakan data tersebut dibuatlah Gambaran Sistem yang sedang berjalan dengan menggunakan Flow Chart.

Setelah itu dilakukan analisis kebutuhan sistem yang diinginkan dan diperlukan oleh pengguna. Berdasarkan hasil analisis ini, digambarkan usulan sistem yang baru dengan menggunakan Diagram Konteks.

\section{2) Perluasan (Elaboration)}

Tahap untuk menganalisis permasalahan utama, membangun arsitektur dasar, mengembang-kan rencana perangkat lunak. Hasil dari fase elaborasi ini adalah Perancangan Sistem, Basis Data dan Interface, yang menggunakan Tools UML.

Perancangan Sistem menggunakan Use Case Diagram dan Activity Diagram. Percanangan Basis Data menggunakan Entity Relationship Diagram dan Kamus Data yang akan menghasilankan tabel-tabel dan relasinya.

Perancangan Interface meliputi pembuatan rancangan inteface Pengguna, Pengelola dan Laporan yang menggunakan Tools $U M L$.

Tahap ini mengubah kebutuhan perangkat lunak ke desain atau model untuk dapat diterjemahkan ke dalam pemrograman (Coding) selanjutnya.

\section{3) Pembuatan (Construction)}

Fokus tahapan ini adalah, pada pembutan atau pengembang perangkat lunak baik komponen utama maupun fitur-fitur pendukungnya, yang selanjutnya akan dilakukan pengujian. Tahap ini mengubah desain atau perancangan ke dalam program
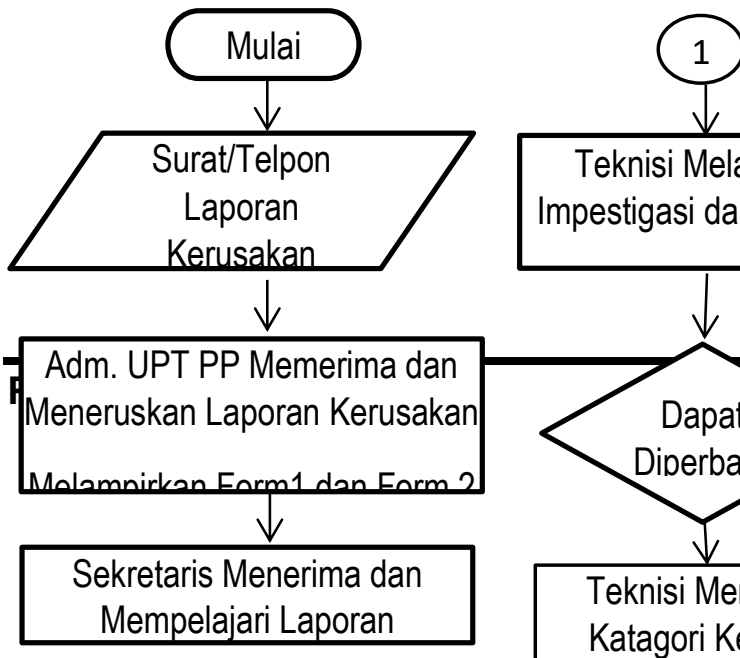

Teknisi Melakukan Impestigasi dan Analisis

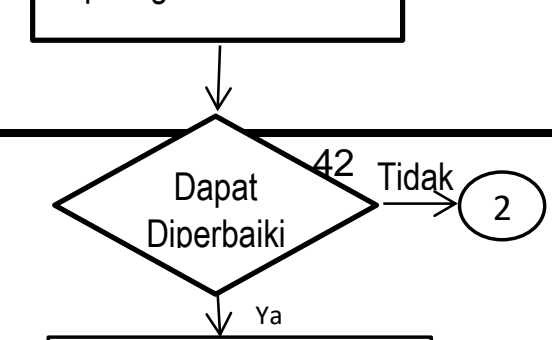

Teknisi Menentukan Katagori Kerusakan BERAT, SEDANG atau perangkat lunak dengan melakukan pengkodenan $P H P$, pembuatan Basis-data MySql dan Pebuatan Server.

Hasil yang diharapkan dari fase ini adalah sebuah produk perangkat lunak yang siap digunakan oleh UPT PP, yaitu sebuah perangkat lunak dengan data terpadu dan terintegrasi yang memadai dalam melayani perawatan dan perbaikan asset Polsri.

\section{4) Peralihan (Transition)}

Tahapan transisi merupakan Tahapan dimana perangkat lunak diserahkan kepada UPT PP, Jurusan dan Unit yang ada di Polsri. Kegiatan-kegiatan yang dilakukan pada fase ini antara lain: memvalidasi sistem baru terhadap harapan pengguna, konversi database operasional, pelatihan bagi pengguna dan pengelola, yang selanjut akan diimplementasikan.

\section{Hasil Dan Pembahasan}

Hasil Rekayasa atau pembangunan perangkat lunak ini, dapat dibahas dalam tahaptahap sebagai berikut:

\subsection{Permulaan (Inception)}

Tahap ini terdiri dari Pengumpulan Data dan Analisis Sistem atau Aplikasi.

\section{1) Pengumpulan Data.}

Pada tahap awal ini, telah dilakukan studi pendahuluan dan pengumpulan data kegiatankegiatan yang ada di UPT-PP POLSRI. Setelah itu dilakukan analisis terhadap kebutuhan sistem yaitu kebutuhan yang diinginkan dan diperlukan. Data untuk analisis didapatkan melalui 3 cara yaitu wawancara, observasi, dan analisis dokumen.

Sistem yang sedang berjalan di UPT-PP POLSRI, dapat digambarkan dengan diagram alir, sebagai berikut: 
2) Analisis Sistem.

Deskripsi (Algoritma) sistem Perbaikan Barang di UPT PP :

- Kerusakan dilaporkan oleh Unit atau Jurusan melalui Surat atau Telpon Kepada Admin UPT PP.

-Laporan diteruskan ke Sekretatis untuk dipelajari

- Sekretaris Menentukan Teknisi yang sesuai.

- Teknisi menuju lokasi dengan membawa Formulis 1 dan 2, untuk melakukan Impestigasi dan Analisis .

- Teknisi menentukan apakah barang dapat diperbaiki atau tidak, bila tidak Kegiatan berkhir.

- Bila dapat diperbaiki, maka teknisi menentukan katagori yaitu; Berat, Sedang atau Ringan.

- Teknisi menentukan apakah perlu pembelian

\subsection{Perluasan (Elaboration)}

Tahap perluasan ini terdiri dari Perancangan: Sistem, Basis Data dan Interface.

1) Perancangan Sistem.

Perancangan Sistem menggunakan Use
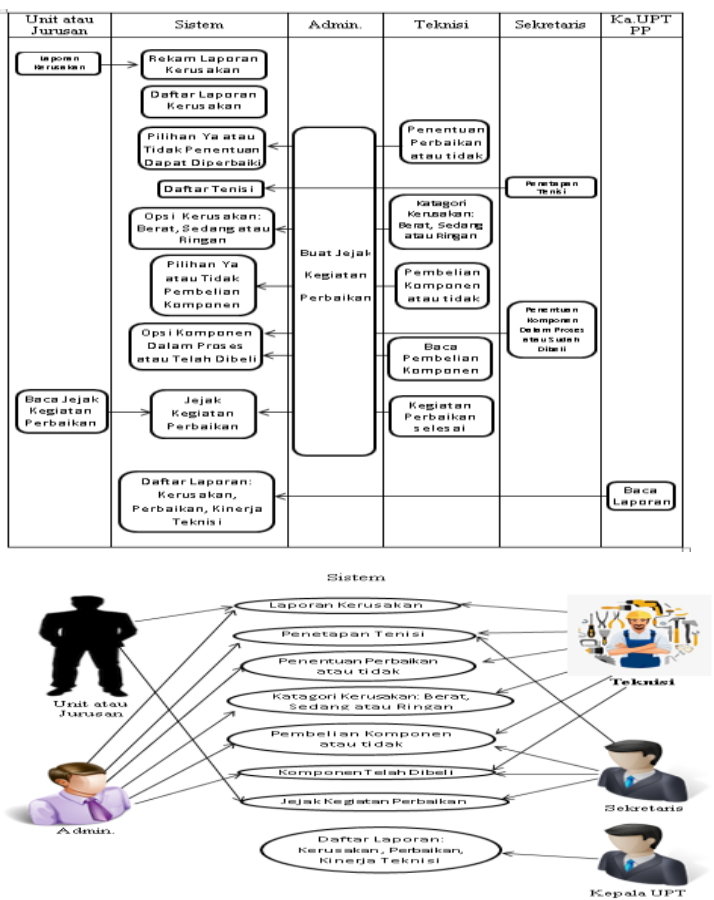

Gambar 5. Diagram Aktifitas Aplikasi

2) Perancangan Basis Data

Untuk merancang basis data dipergunakan komponen, bila tidak, langsung dilakukan perbaikan.

- Bila Perlu pembelian komponen, maka teknisi membuat laporan sekretaris.

- Tenisi menunggu Proses Pembelian Komponen sampai selesai.

- Teknisi melakukan perbaikan.

- Teknisi Mengisi dan mebubuhi paraf Formulir 1 dan 2

- Teknisi menghadap ka. Unit atau Kajur memintan tanda tanda persejuan pada Formulir 1 dan 2.

- Teknisi menghadap Sekretatis meminta faraf persejuan pada Formulir 1 dan 2.

- Admin. mengarsipkan Formulir 1 dan 2.

- Kegiatan selesai.

Sistem yang diusulan disusun dengan menggunakan diagram konteks, sebagai berikut:

\section{Case dan Activity Diagram.}

\section{Use Case Diagram}

Menggambarkan fungsionalitas yang diharapkan dari sistem Perbaikan Barang di UPT PP. Use case ini meerepresentasikan sebuah interaksi aktor, antara lain; Unit atau Jurusan, Admin, Teknisi, Sekrreteris dan Kepala UPT PP yang ditampilkan pada Gambar 4.

\section{Activity Diagram}

Activity Diagram menggambarkan aktivitas didalam sistem Perbaikan Barang di UPT PP. Diagram ini meerepresentasikan aktivitas aktor, antara lain; Unit atau Jurusan, Admin, Teknisi, Sekrreteris dan Kepala UPT PP yang ditampilkan pada Gambar 5.

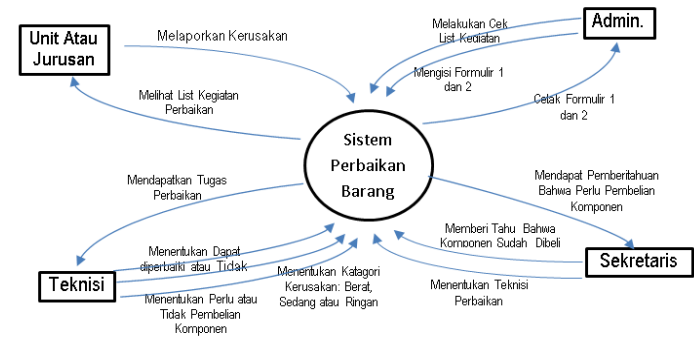

Entity Relationship Diagram (ERD) dan Kamus Data 
Entity Relationship Diagram (ERD)

Diagram ini yang dibuat untuk merancang basis data, dipergunakan untuk memperlihatkan hubungan atau relasi antar entitas atau objek yang terlibat dalam aplikasi, beserta atributnya.

Entitas atau objek yaitu Pengguna merupakan elemen di lingkungan Polsri, Perbaikan merupakan arus informasi perbaikan alat.

\section{Kamus Data}

Kamus data yang tersimpan dalam basis data pada aplikasi ini, yaitu terdiri dari tabeltabel, sebagai berikut:

a) Tabel Pengguna

Tabel Pengguna berfungsi untuk menyimpan semua data pengguna yang meliputi Unit atau Jurusan yang berada dilingkungan Posri dan pengelola yaitu UPTPP, dengan struktur sebagai berikut: pengguna $=@$ id_pengguna + nama_pengguna+katagori_pengguna+sandi

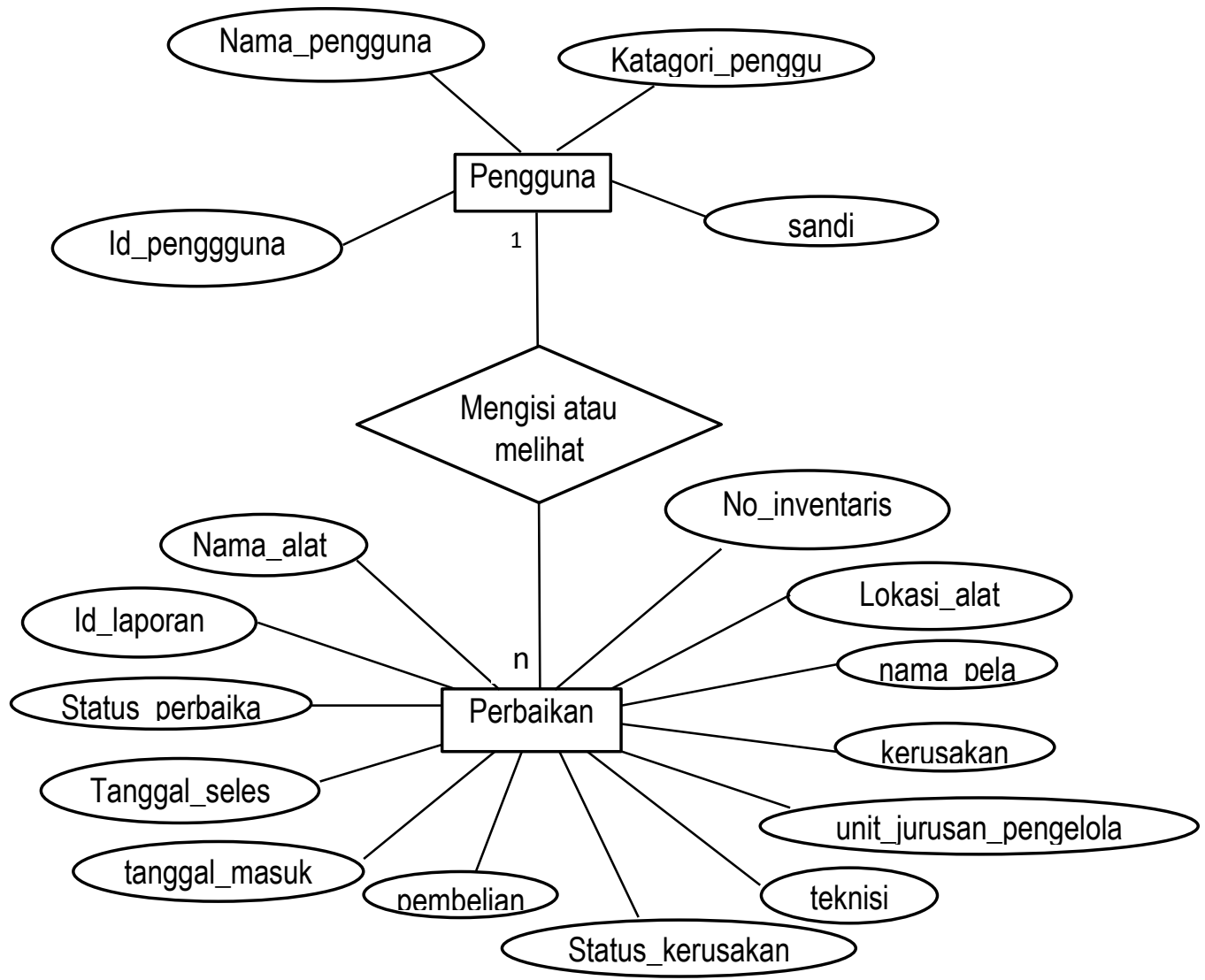

Gambar 6. Entity Relationship Diagram Perbaikan Alat 


$$
\begin{array}{ll}
\text { id_pengguna } & =\operatorname{int}\{11\} \\
\text { katagori_pengguna } & =\operatorname{varchar}\{50\} \\
\text { nama_pengguna } & =\operatorname{varchar}\{50\} \\
\text { sandi } & =\operatorname{varchar}\{50\}
\end{array}
$$

b) Tabel Perbaikan

Tabel Perbaikan berfungsi untuk menyimpan semua data perbaikan alat dari Unit atau Jurusan yang perbaiki UPT_PP, dengan struktur sebagai berikut:

perbaikan = @ id_laporan + nama_alat + nomor_inven + lokasi_alat + nama_pelapor + kerusakan + unit_jurusan_pengelola + teknisi + status_kerusakan + pembelian + tanggal_masuk + tanggal_selesai + status_perbaikan

$\begin{array}{ll}\text { id_laporan } & =\operatorname{int}\{11\} \\ \text { nama_alat } & =\operatorname{varchar}\{100\} \\ \text { nomor_inven } & =\operatorname{varchar}\{50\} \\ \text { lokasi_alat } & =\operatorname{varchar}\{50\} \\ \text { nama_pelapor } & =\operatorname{varchar}\{50\} \\ \text { kerusakan } & =\operatorname{text}\{20\} \\ \text { unit_jurusan_pengelola } & =\operatorname{vint}\{11\} \\ \text { teknisi } & =\operatorname{varchar}\{50\} \\ \text { status_kerusakan } & =\operatorname{varchar}\{50\} \\ \text { pembelian } & =\operatorname{varchar}\{50\} \\ \text { tanggal_masuk } & =\text { date } \\ \text { tanggal_selesai } & =\text { date } \\ \text { status_perbaikan } & =\operatorname{varchar}\{50\}\end{array}$

\section{3) Perancangan Interface}

Perancangan interface meleputi Unit atau Jurusan, Admin, Sekretaris, Ka. UPT PP, namun sebelum masuk ke interface tersebut, perlu dibuat interface Login.

\section{Rancangan Interface Login}

Interface ini akan menjadi pintu masuk ke dalam Aplikasi ini, setiap pengguna perlu memasukan Pilih Katagori dan Kata Sandi. Katagori terdiri dari: Unit Atau Jurusan dan Pengelola. Unit atau Jurusan terdiri unit yang berada dilingkungan Polsri dan 11 Jurusan.

Rancangan Interface Unit atau Jurusan

Rancangan Interface Unit atau Jurusan ini terdiri dari 2 bagian yaitu: untuk pilihan kegiatan laporan kerusakan dan melihat melihat barang yang sedang diperbaiki.
Pada interface Admin. UPT PP dapat melihat saja atau menperbaiki semua field dan memilih semua opsi.

Rancangan Interface Sekretaris.

Pada interface Sekretaris UPT PP dapat melihat saja atau menperbaiki field Teknisi UPT PP saja, atau melihat dan mencetak SemuaTabel Laporan yang akan dirancang berikut.

\section{Rancangan Interface Teknisi.}

Pada interface ini Teknisi UPT PP dapat melihat saja, field yang tampil.

\section{Rancangan Interface Kapala UPT-PP}

Pada interface ini Kepala UPT PP dapat melihat saja, field yang tampil. Selanjutnya Kepala UPT PP. dapat melihat SemuaTabel Laporan yang akan dirancang berikutnya.

Rancangan Interface Tabel Laporan.

Rancangan Interface Tabel Laporan ini dalam bentuk tabel, yaitu tabel Laporan Barang sedang diperbaiki dan Barang yang selesai diperbaiki. Tabel-tabel ini dapat dilihat secara keseluhan dan dapat juga dilihat berdasar Teknisi yang mengerjakan perbaikan, atau berdasarkan rentang Tanggal tertentu.

\subsection{Pembuatan (Construction)}

Pada tahapan akan dilakukan pembuatan atau pengembang perangkat yang selanjutnya akan dilakukan pengujian. Tahap ini mengubah desain atau perancangan ke dalam program perangkat lunak dengan melakukan pengkodean PHP, pembuatan Basis-data MySql dan Pembuatan Server.

Hasil dari tahap ini adalah sebuah produk perangkat lunak yang siap digunakan oleh UPT PP, yaitu sebuah perangkat lunak dengan data terpadu dan terintegrasi yang memadai dalam melayani perawatan dan perbaikan aset Polsri.

Hasil dari pembuatan basis data PhpMyAdmin dengan nama: dbuptpp, yang didalamnya terdapat tabel-tabel dengan 
nama: Pengguna dan Perbaikan, yaitu:

\section{1) Tabel Pengguna}

Tabel Pengguna berfungsi untuk menyimpan semua data pengguna yang meliputi Unit atau Jurusan yang berada dilingkungan Posri dan pengelola yaitu UPT-PP, dengan struktur sebagai berikut:

Tabel 1: Pengguna

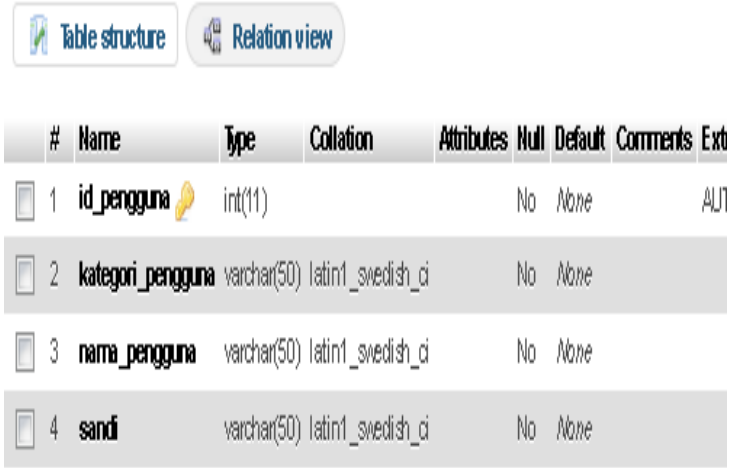

Sumber: Hasil Pengolahan.

2) Tabel Perbaikan

Tabel Perbaikan berfungsi untuk menyimpan semua data perbaikan alat dari Unit atau Jurusan yang perbaiki UPT_PP, dengan struktur sebagai berikut:

Tabel 2: Perbaikan

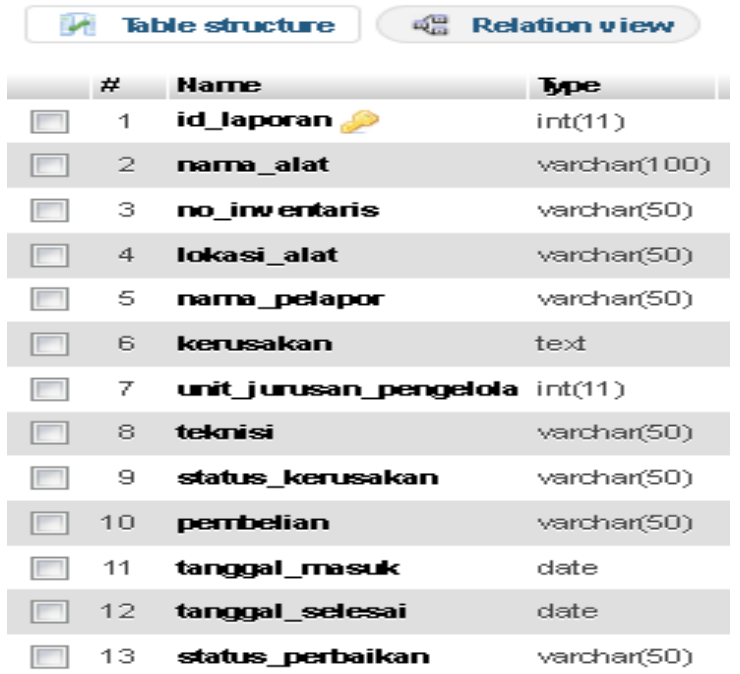

Sumber: Hasil Pengolahan.

Hasil dari pengkodean Php menghasilkan halaman: Login, Unit atau Jurusan, Admin, Teknisi, Sekretaris, Ka.
UPT PP dan Laporan, adalah seperti di bawah ini:

\section{1) Halaman Login}

Halaman ini menjadi pintu masuk ke dalam Aplikasi ini, setiap pengguna perlu memasukan Pilih Katagori dan Kata Sandi. Katagori terdiri dari:Unit Atau Jurusan dan Pengelola. Unit atau Jurusan terdiri unit yang berada dilingkungan Polsri dan 11 Jurusan, tampilannya sebagai berikut:

\section{Unit Pelayanan Terpadu Perawatan dan Perbaikan (UPT PP)}

Pilih Katagori Pengguna:

\begin{tabular}{|l|}
\hline Unit Atau Jurusan $\quad \mathbf{\nabla}$ \\
\hline
\end{tabular}

Pilih Pengguna:

Manajemen Informatika $\quad \mathbf{\nabla}$

Masukan Kata Sandi :

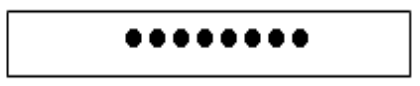

\section{Login}

Gambar 7. Rancangan Interface Login

\section{2) Halaman Unit atau Jurusan}

Interface Unit atau Jurusan ini terdiri dari 2 bagian yaitu: untuk pilihan kegiatan laporan kerusakan dan melihat melihat barang yang sedang diperbaiki, yaitu:

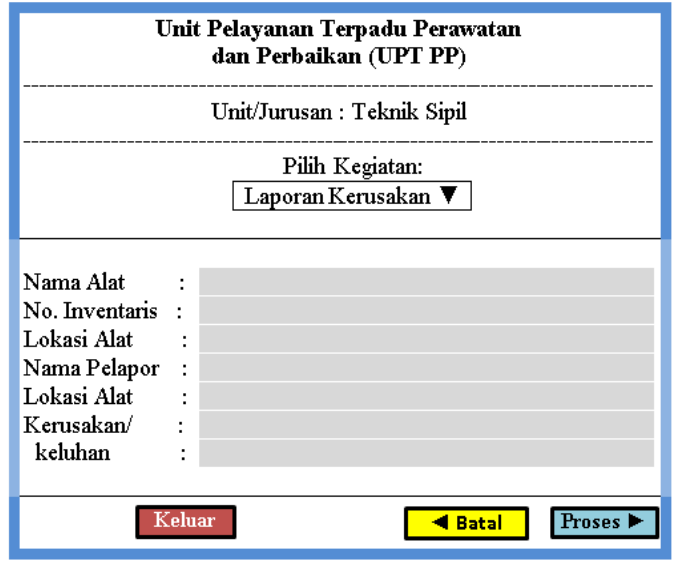


Gambar 8. Rancangan Interface Unit atau Jurusan.

\section{3) Halaman Admin.}

Pada interface Admin. UPT PP dapat memilih 2 kegiatan, yaitu: melihat saja record laporan kerusakan atau menperbaiki semua field dan memilih semua opsi. Tampilannya sebagai berikut:

\begin{tabular}{|c|c|}
\hline \multicolumn{2}{|c|}{$\begin{array}{c}\text { Unit Pelayanan Terpadu Perawatan } \\
\text { dan Perbaikan (UPT PP) }\end{array}$} \\
\hline \multicolumn{2}{|r|}{ Pengelola : Admin. } \\
\hline \multicolumn{2}{|r|}{ Pilih Kegiatan: } \\
\hline \multicolumn{2}{|r|}{ Ubah Record $\mathbf{7}$} \\
\hline Nama Alat & 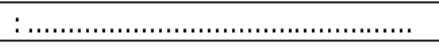 \\
\hline No. Inventaris & $: \ldots \ldots \ldots \ldots \ldots \ldots \ldots \ldots \ldots \ldots \ldots \ldots \ldots \ldots \ldots \ldots \ldots$ \\
\hline Lokasi Alat & 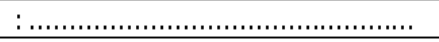 \\
\hline Nama Pelapor & 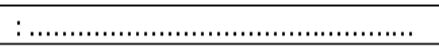 \\
\hline \multicolumn{2}{|c|}{ 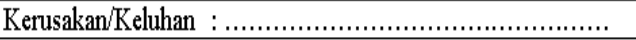 } \\
\hline \multicolumn{2}{|c|}{ Unit atau Jurusan $\quad: \ldots$} \\
\hline \multicolumn{2}{|c|}{ 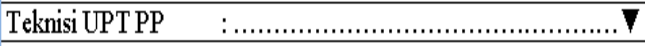 } \\
\hline \multicolumn{2}{|c|}{ 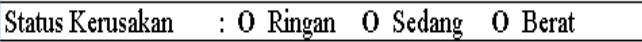 } \\
\hline \multicolumn{2}{|c|}{ Pembelian Komponen: 0 Ya 0 Tidak } \\
\hline \multicolumn{2}{|c|}{ 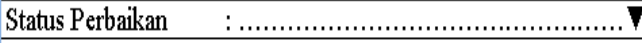 } \\
\hline \multicolumn{2}{|c|}{ Tanggal Masuk : ..................... Tanggal Selesai : ..... } \\
\hline Keluar & Hapus Simpan 4 Sebelum Berikut \\
\hline
\end{tabular}

Gambar 9. Rancangan Interface Admin.

\section{4) Halaman Sekretaris,}

Pada interface initer dapat 3 pilihan kegiatan, Sekretaris UPT PP dapat melihat saja atau menperbaiki field Teknisi UPT PP saja atau melihat tabel laporan.

\begin{tabular}{|c|c|}
\hline \multicolumn{2}{|c|}{$\begin{array}{c}\text { Unit Pelayanan Terpadu Perawatan } \\
\text { dan Perbaikan (UPT PP) }\end{array}$} \\
\hline \multicolumn{2}{|r|}{ Pengelola : Sekretaris } \\
\hline \multicolumn{2}{|r|}{ Pilih Kegiatan: } \\
\hline & $\begin{array}{ll}\text { Ubah Teknisi } & \boldsymbol{\nabla} \\
\end{array}$ \\
\hline Nama Alat & 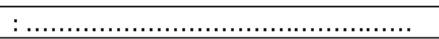 \\
\hline No. Inventaris & 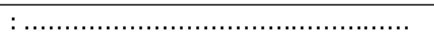 \\
\hline Lokasi Alat & 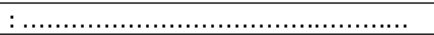 \\
\hline Nama Pelapor $\quad:$. & 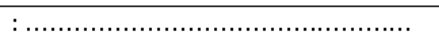 \\
\hline \multicolumn{2}{|c|}{ Kerusakan/Keluhan $: \ldots \ldots \ldots \ldots \ldots \ldots \ldots \ldots \ldots \ldots \ldots \ldots \ldots$} \\
\hline Unit atau Jurusan $\quad:$ & : $\ldots \ldots \ldots \ldots \ldots \ldots \ldots \ldots \ldots \ldots \ldots \ldots \ldots \ldots \ldots$ \\
\hline Teknisi UPT PP & $: \ldots \ldots \ldots \ldots \ldots \ldots \ldots \ldots \ldots \ldots \ldots \ldots \ldots \ldots \ldots, \boldsymbol{\nabla}$ \\
\hline Status Kerusakan : & : $O$ Ringan $O$ Sedang $O$ Berat \\
\hline \multicolumn{2}{|c|}{ Pembelian Komponen: O Ya O Tidak } \\
\hline Status Perbaikan : & : $\ldots \ldots \ldots \ldots \ldots \ldots \ldots \ldots \ldots \ldots \ldots \ldots \ldots \ldots \ldots$ \\
\hline \multicolumn{2}{|c|}{ Tanggal Masuk : ................. Tanggal Selesai : ................. } \\
\hline Keluar & 4 Sebelum Berikut \\
\hline
\end{tabular}

Gambar 10. Rancangan Interface Sekretaris

\section{5) Halaman Teknisi}

Pada interface ini Teknisi UPT PP dapat melihat saja record kerusakan barang.Tampilannya sebagai berikut:

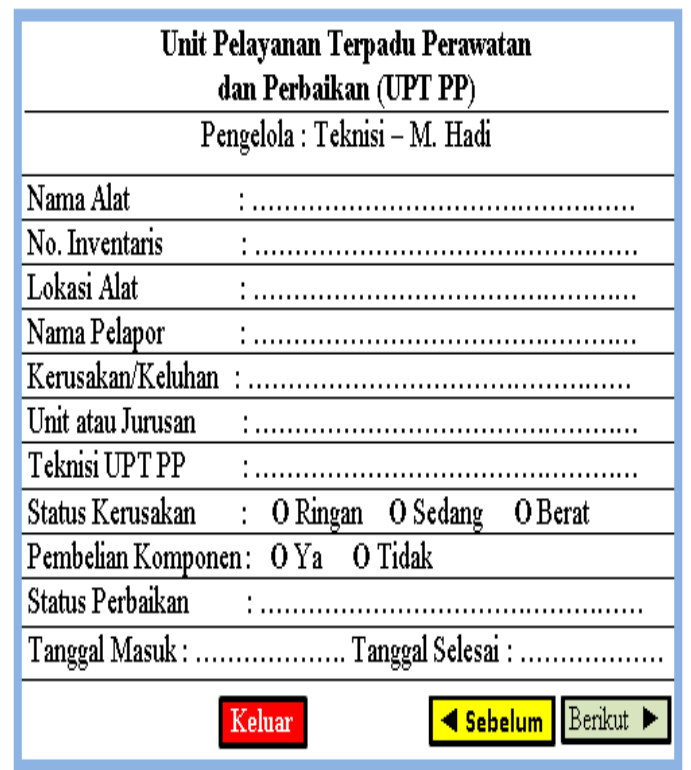

Gambar 11. Rancangan Interface Teknisi

\section{6) Halaman Ka. UPT-PP}

Pada interface ini Kepala UPT PP dapat memilih kegiatan, yaitu: melihat Record serta dapat melihat Semua Tabel Laporan pada Interface berikutnya. Tampilannya adalah:

\begin{tabular}{|c|c|}
\hline \multicolumn{2}{|c|}{$\begin{array}{c}\text { Unit Pelayanan Terpadu Perawatan } \\
\text { dan Perbaikan (UPT PP) }\end{array}$} \\
\hline \multicolumn{2}{|r|}{$\begin{array}{l}\text { Pengelola : Ka. UPT PP } \\
\text { Pilih Kegiatan: }\end{array}$} \\
\hline \multicolumn{2}{|r|}{$\begin{array}{|ll|}\text { Lihat Record } \quad \boldsymbol{\nabla} \\
\end{array}$} \\
\hline Nama Alat & 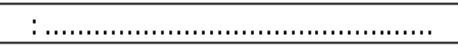 \\
\hline No. Inventaris & 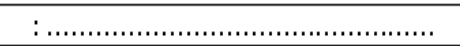 \\
\hline Lokasi Alat & 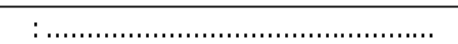 \\
\hline Nama Pelapor & $: \ldots \ldots \ldots \ldots \ldots \ldots \ldots \ldots \ldots \ldots \ldots \ldots \ldots \ldots \ldots \ldots$ \\
\hline Kerusakan/Keluhan & 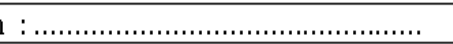 \\
\hline Unit atau Jurusan & 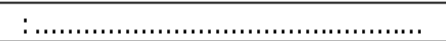 \\
\hline Teknisi UPT PP & 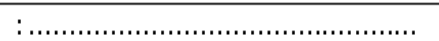 \\
\hline Status Kerusakan & : 0 Ringan 0 Sedang 0 Berat \\
\hline \multicolumn{2}{|c|}{ Pembelian Komponen: 0 Ya 0 Tidak } \\
\hline Status Perbaikan & 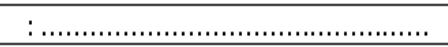 \\
\hline \multicolumn{2}{|c|}{ Tanggal Masuk : ................. Tanggal Selesai : ................ } \\
\hline Keluar & 4 Sebelum Berikut \\
\hline
\end{tabular}

Gambar 12. Rancangan Interface Teknisi 
Halaman Tabel Laporan.

Halaman Tabel Laporan hanya dapat diakses oleh Sekretaris dan Ka. UPT PP. Terdapat 3 Pilihan, yaitu menampilan tabel: Laporan Barang sedang diperbaiki, Barang yang selesai diperbaiki dan Cetak Tabel Laporan.

\begin{tabular}{|c|}
\hline $\begin{array}{c}\text { Unit Pelaynanan Terpadu Peraxatan } \\
\text { dan Pemellihnarana (UPT PP) }\end{array}$ \\
\hline 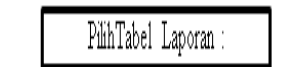 \\
\hline 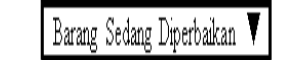 \\
\hline
\end{tabular}

Tabel Laporan Barang sedang gutperbaiki

\begin{tabular}{|c|c|c|c|c|c|c|c|c|c|}
\hline $\begin{array}{l}\text { Nama } \\
\text { Alat }\end{array}$ & $\begin{array}{l}\text { Nomor } \\
\text { Inventa } \\
\text { IIs }\end{array}$ & $\begin{array}{c}\text { Loka } \\
\text { st } \\
\text { Alat }\end{array}$ & $\begin{array}{l}\text { Nama } \\
\text { Pelapor }\end{array}$ & $\begin{array}{l}\text { Unit } \\
\text { attall } \\
\text { Juncisan }\end{array}$ & $\begin{array}{l}\text { Tekrisis } \\
\text { TPPT } \\
\text { PP }\end{array}$ & $\begin{array}{l}\text { Status } \\
\text { Renus } \\
\text { akant }\end{array}$ & $\begin{array}{l}\text { Pembeli } \\
\text { Rompo. }\end{array}$ & $\begin{array}{l}\text { Stands } \\
\text { Perbad } \\
\text { kan }\end{array}$ & $\begin{array}{l}\text { Tangal } \\
\text { Masulk. }\end{array}$ \\
\hline$x 0 x x$ & $x 0 x x x$ & $x x x x$ & $x>0 x a x$ & $x \mathrm{x} x \mathrm{xax}$ & $x \mathrm{x} x \mathrm{x} x \mathrm{x}$ & 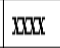 & xacoxax & $\mathrm{xxxcx}$ & $x x x x x$ \\
\hline
\end{tabular}

\section{Simpulan}

Aplikasi ini terdiri dari beberapa halaman, diantaranya halaman login, halaman Unit dan Jurusan, halaman Admin., halaman Teknisi, halaman Sekretaris dan halaman Ketua UPT-PP dengan akses yang diatur sesuai dengan kebutuhan organisi.

Aplikasi ini menghasilkan luaran berupa laporan yang dapat di akses oleh Kepala UPT-PP untuk mengontrol kinerja dan pelayan dalam perbaikan alat.

\section{Ucapan Terima Kasih}

Penulis mengucapkan terima kasih kepada: Tim Redaksi Jurnal PATANI yang telah memberi kesempatan, agar artikel ilmiah ini dapat diterbitkan.

Serta Kepada Pusat P3M Polsri yang telah menyalurkan dana untuk terselenggaranya Penelitian ini.

\section{Daftar Pustaka}

Eben Hewitt, Cassandra. 2010. The Definitive Guide, United States of America, O'Reilly Media, Inc
Fahtansyah. 2012. Analisa dan Perancangan Sistem Informasi. Andi : Yogyakarta.

Febrian. 2007. Mudah Tepat Singkat Pemrograman HTML. CV. Yrama Widya : Bandung

Fowler, M.; Beck, K.; Brant, J.; Opdyke, W. F.; Roberts, D. 2002. Refactoring: Improving the Design of Existing Code. Addison-Wesley.

Jacobson dan Pan Wei Ng. 2004. AspectOriented Software Development with Use Cases. Addison Wesley. USA.

Kadir. 2008. Dasar Pemrograman Web Dinamis Menggunakan PHP,Andi,Yogyakarta

M. Suyanto. 2003, Strategi Periklanan pada E-Commerce Perusahaan Top Dunia, Andi, Yogyakarta.

Mulyanto (2010). Analisis Sistem Informasi. Andi : Yogyakarta.

Rickyanto (2003). Belajar Database Menggunakan MySQL. Andi : Yogyakarta

Roger S Pressman. 2001. Software Engineering: A Practitioner's Approach ( $5^{\text {th }} E d$.). Mc Graw-Hill. USA.

Taryana Suryana (2007), E-commerce Menggunakan PHP dan MySQL, Graha Ilmu, Yogyakarta.

Sanjaya (2006). Pemrograman Web PHP. INFORMATIKA : Bandung.

Sudarmo (2006). Menguasai PHP MySQL Dalam Sekejap Tanpa Guru. Kuncikom : Jakarta. 